Race Ethnicity and Education

\title{
Whose culture has capital? A critical race theory discussion of community cultural wealth
}

\author{
Tara J. Yosso
}

To cite this article: Tara J. Yosso (2005) Whose culture has capital? A critical race theory discussion of community cultural wealth, Race Ethnicity and Education, 8:1, 69-91, DOI: 10.1080/1361332052000341006

To link to this article: https://doi.org/10.1080/1361332052000341006

曲 Published online: 23 Aug 2006.

Submit your article to this journal $\pi$

Џ Article views: 38715

Citing articles: 965 View citing articles 4 


\title{
Whose culture has capital? A critical race theory discussion of community cultural wealth
}

\author{
Tara J. Yosso* \\ University of California, USA
}

This article conceptualizes community cultural wealth as a critical race theory (CRT) challenge to traditional interpretations of cultural capital. CRT shifts the research lens away from a deficit view of Communities of Color as places full of cultural poverty disadvantages, and instead focuses on and learns from the array of cultural knowledge, skills, abilities and contacts possessed by socially marginalized groups that often go unrecognized and unacknowledged. Various forms of capital nurtured through cultural wealth include aspirational, navigational, social, linguistic, familial and resistant capital. These forms of capital draw on the knowledges Students of Color bring with them from their homes and communities into the classroom. This CRT approach to education involves a commitment to develop schools that acknowledge the multiple strengths of Communities of Color in order to serve a larger purpose of struggle toward social and racial justice.

\section{Introduction}

Theory, then, is a set of knowledges. Some of these knowledges have been kept from usentry into some professions and academia denied us. Because we are not allowed to enter discourse, because we are often disqualified and excluded from it, because what passes for theory these days is forbidden territory for us, it is vital that we occupy theorizing space, that we not allow white men and women solely to occupy it. By bringing in our own approaches and methodologies, we transform that theorizing space. (Anzaldúa, 1990, p. $x x v$, emphasis in original)

In the epigraph above, Gloria Anzaldúa (1990) calls on People of Color to transform the process of theorizing. This call is about epistemology-the study of sources of knowledge. Scholars such as Gloria Ladson-Billings (2000) and Dolores Delgado Bernal (1998, 2002) have asked: whose knowledge counts and whose knowledge is discounted? Throughout US history, race and racism have shaped this

\footnotetext{
*Department of Chicana and Chicano Studies, University of California, Santa Barbara, Santa Barbara, CA 93106, USA. Email: yosso@chicst.ucsb.edu
} 
epistemological debate (Scheurich \& Young, 1997; Lopez \& Parker, 2003). Indeed, it has been over a century since DuBois $(1903,1989)$ predicted that racism would continue to emerge as one of the United States' key social problems. Racism overtly shaped US social institutions at the beginning of the twentieth century and continues, although more subtly, to impact US institutions of socialization in the beginning of the twenty-first century. Researchers, practitioners and students are still searching for the necessary tools to effectively analyze and challenge the impact of race and racism in US society.

In addressing the debate over knowledge within the context of social inequality, Pierre Bourdieu (Bourdieu \& Passeron, 1977) argued that the knowledges of the upper and middle classes are considered capital valuable to a hierarchical society. If one is not born into a family whose knowledge is already deemed valuable, one could then access the knowledges of the middle and upper class and the potential for social mobility through formal schooling. Bourdieu's theoretical insight about how a hierarchical society reproduces itself has often been interpreted as a way to explain why the academic and social outcomes of People of Color are significantly lower than the outcomes of Whites. The assumption follows that People of Color 'lack' the social and cultural capital required for social mobility. As a result, schools most often work from this assumption in structuring ways to help 'disadvantaged' students whose race and class background has left them lacking necessary knowledge, social skills, abilities and cultural capital (see Valenzuela, 1999).

This interpretation demonstrates Anzaldúa's point: 'If we have been gagged and disempowered by theories, we can also be loosened and empowered by theories' (Anzaldúa, 1990, p. xxvi). Indeed, if some knowledges have been used to silence, marginalize and render People of Color invisible, then 'Outsider' knowledges (Hill Collins, 1986), mestiza knowledges (Anzaldúa, 1987) and transgressive knowledges (hooks, 1994) can value the presence and voices of People of Color, and can reenvision the margins as places empowered by transformative resistance (hooks, 1990; Delgado Bernal, 1997; Solórzano \& Delgado Bernal, 2001). Critical race theory (CRT) listens to DuBois' racial insight and offers a response to Anzaldúa's theoretical challenge. CRT is a framework that can be used to theorize, examine and challenge the ways race and racism implicitly and explicitly impact on social structures, practices and discourses.

Below, I discuss the ways CRT centers Outsider, mestiza, transgressive knowledges. After outlining the theoretical framework of CRT, I critique the assumption that Students of Color come to the classroom with cultural deficiencies. Utilizing a CRT lens, I challenge traditional interpretations of Bourdieuean cultural capital theory (Bourdieu \& Passeron, 1977) and introduce an alternative concept called community cultural wealth. Then, I outline at least six forms of capital that comprise community cultural wealth and most often go unacknowledged or unrecognized. In examining some of the under-utilized assets Students of Color bring with them from their homes and communities into the classroom, this article notes the potential of community cultural wealth to transform the process of schooling. 


\section{Critical race theory in education}

CRT draws from and extends a broad literature base of critical theory in law, sociology, history, ethnic studies and women's studies. Kimberlé Crenshaw (2002) explains that in the late 1980s, various legal scholars felt limited by work that separated critical theory from conversations about race and racism. Alongside other 'Outsider' scholars (Hill Collins, 1986) Crenshaw (2002) was 'looking for both a critical space in which race was foregrounded and a race space where critical themes were central' (p. 19). Mari Matsuda (1991) defined that CRT space as:

... the work of progressive legal scholars of color who are attempting to develop a jurisprudence that accounts for the role of racism in American law and that work toward the elimination of racism as part of a larger goal of eliminating all forms of subordination. (p. 1331)

In previous work, I describe a genealogy of CRT that links the themes and patterns of legal scholarship with the social science literature (Solórzano \& Yosso, 2001). Figure 1 addresses some of this intellectual history. ${ }^{1}$

In its post-1987 form, CRT emerged from criticisms of the Critical Legal Studies (CLS) movement. CLS scholars questioned the role of the traditional legal system in legitimizing oppressive social structures. With this insightful analysis, CLS scholarship emphasized critique of the liberal legal tradition as opposed to offering strategies for change. Scholars such as Derrick Bell and Alan Freeman asserted that one reason why the CLS critique of the law could not offer strategies for social transformation was because it failed to incorporate race and racism into the analysis (Delgado, 1995a; Ladson-Billings, 1998). Not listening to the lived experiences and histories of those oppressed by institutionalized racism limited CLS scholarship. This argument had also been taking place in social science and history circles, specifically in ethnic and women's studies scholarship.

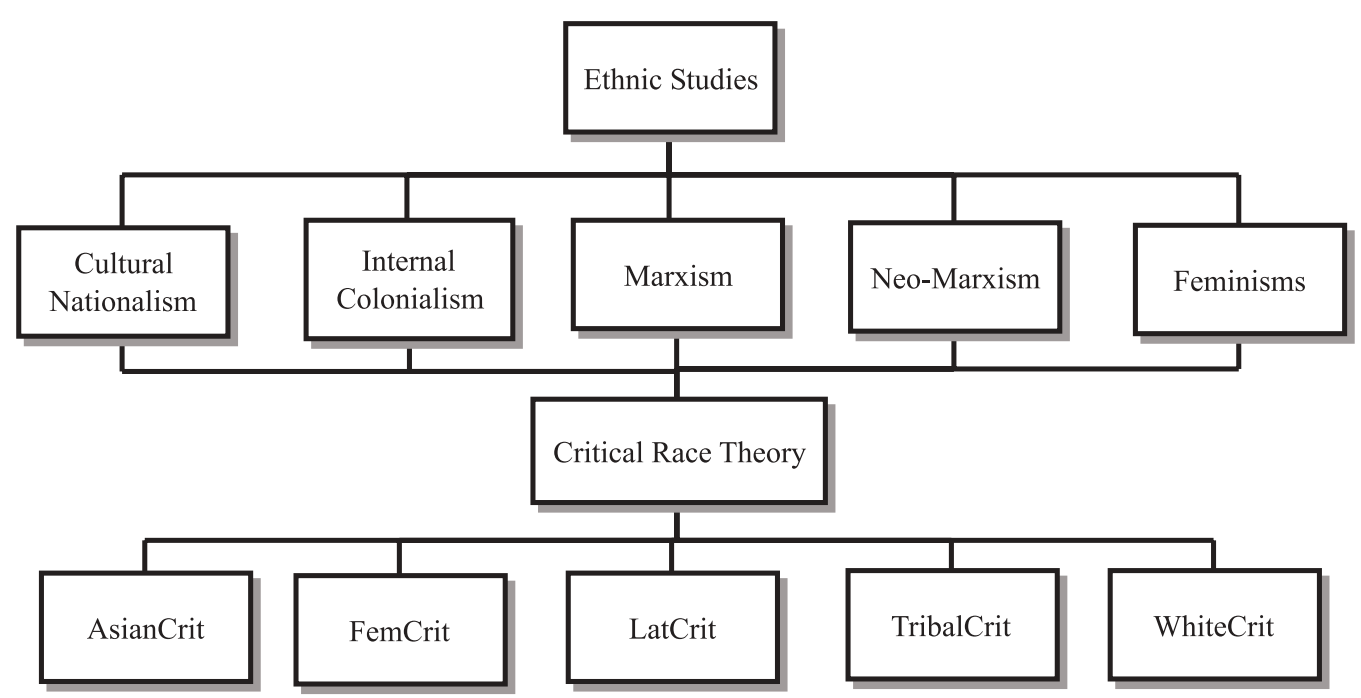

Figure 1. An intellectual genealogy of critical race theory 
Critical race theorists began to pull away from CLS because the critical legal framework restricted their ability to analyze racial injustice (Delgado, 1988; Crenshaw et al., 1995; Delgado \& Stefancic, 2001; Crenshaw, 2002). Initially, CRT scholarship focused its critique on the slow pace and unrealized promise of Civil Rights legislation. As a result, many of the critiques launched were articulated in Black vs White terms. Women and People of Color who felt their gendered, classed, sexual, immigrant and language experiences and histories were being silenced, challenged this tendency toward a Black/White binary. They stressed that oppression in the law and society could not be fully understood in terms of only Black and White. Certainly, African Americans have experienced a unique and horrendous history of racism and other forms of subordination in the US. Other People of Color have their own histories that likewise have been shaped by racism and the intersecting forms of subordination (Espinoza \& Harris, 1998). By offering a two-dimensional discourse, the Black/White binary limits understandings of the multiple ways in which African Americans, Native Americans, Asian/Pacific Islanders, Chicanas/os, and Latinas/os continue to experience, respond to, and resist racism and other forms of oppression.

For example, Latina/o critical race (LatCrit) theory extends critical race discussions to address the layers of racialized subordination that comprise Chicana/o, Latina/o experiences (Arriola, 1997, 1998; Stefancic, 1998). LatCrit scholars assert that racism, sexism and classism are experienced amidst other layers of subordination based on immigration status, sexuality, culture, language, phenotype, accent and surname (Montoya, 1994; Johnson, 1999). Indeed, the traditional paradigm for understanding US race relations is often a Black/White binary, which limits discussions about race and racism to terms of African American and White experiences (Valdes, 1997, 1998). Like Manning Marable (1992), who defines racism as 'a system of ignorance, exploitation and power used to oppress African Americans, Latinos, Asians, Pacific Americans, American Indians, and other people on the basis of ethnicity, culture, mannerisms, and color' (p. 5), CRT scholarship has benefited from scholarship addressing racism at its intersections with other forms of subordination (Crenshaw, 1989, 1993).

Over the years, the CRT family tree has expanded to incorporate the racialized experiences of women, Latinas/os, Native Americans and Asian Americans (see Figure 1). For example, LatCrit, TribalCrit and AsianCrit are branches of CRT, evidencing Chicana/o, Latina/o, Native American and Asian American communities' ongoing search for a framework that addresses racism and its accompanying oppressions beyond the Black/White binary (Ikemoto, 1992; Chang, 1993, 1998; Chon, 1996; Delgado, 1997; Williams, 1997; Brayboy, 2001, 2002). Women of Color have also challenged CRT to address feminist critiques of racism and classism through FemCrit theory (Caldwell, 1995; Wing, 1997, 2000). In addition, White scholars have expanded CRT with WhiteCrit, by 'looking behind the mirror' to expose White privilege and challenge racism (Delgado \& Stefancic, 1997).

CRT's branches are not mutually exclusive or in contention with one another. Naming, theorizing and mobilizing from the intersections of racism, need not initiate 
some sort of oppression sweepstakes-a competition to measure one form of oppression against another. As Cherrie Moraga (1983) writes,

The danger lies in ranking the oppressions. The danger lies in failing to acknowledge the specificity of the oppression. The danger lies in attempting to deal with oppression purely from a theoretical base. Without an emotional, heartfelt grappling with the source of our own oppression, without naming the enemy within ourselves and outside of us, no authentic, non-hierarchical connection among oppressed groups can take place. (pp. 52-53)

Indeed, racism and its intersections with other forms of subordination shape the experiences of People of Color very differently than Whites (Bell, 1986; 1998; Essed, 1991; Baca Zinn, 1989). Still, the popular discourse in the US, as well as the academic discourse, continues to be limited by the Black/White binary. CRT adds to efforts to continue to expand this dialogue to recognize the ways in which our struggles for social justice are limited by discourses that omit and thereby silence the multiple experiences of People of Color (Ellison, 1990).

As a student of Chicana/o Studies, the theoretical models informing my work included the Internal Colonial model (Bonilla \& Girling, 1973; Blauner, 2001), Marxism (Bowles \& Gintis, 1976; Barrera, 1979), Chicana and Black feminisms (Anzaldúa, 1987; hooks, 1990; Zavella, 1991; Hurtado, 1996; Hill Collins, 1998, 2000; Saldivar-Hull, 2000) and cultural nationalism (Asante, 1987). Even with all of their strengths, each of these frameworks had certain blindspots that limited my ability to examine racism. Now, as a professor of Chicana/o Studies, my work is informed by the hindsight of CRT and its genealogical branches. To document and analyze the educational access, persistence and graduation of underrepresented students, I draw on my interdisciplinary training and those theoretical models whose popularity may have waned since the 1960s and 1970s, but whose commitment to speaking truth to power continues to address contemporary social realities.

For the field of education, Daniel Solórzano $(1997,1998)$ identified five tenets of CRT that can and should inform theory, research, pedagogy, curriculum and policy: ${ }^{2}$ (1) the intercentricity of race and racism; (2) the challenge to dominant ideology; (3) the commitment to social justice; (4) the centrality of experiential knowledge; and (5) the utilization of interdisciplinary approaches.

1. The intercentricity of race and racism with other forms of subordination. CRT starts from the premise that race and racism are central, endemic, permanent and a fundamental part of defining and explaining how US society functions (Bell, 1992; Russell, 1992). CRT acknowledges the inextricable layers of racialized subordination based on gender, class, immigration status, surname, phenotype, accent and sexuality (Crenshaw, 1989, 1993; Valdes et al., 2002).

2. The challenge to dominant ideology. CRT challenges White privilege and refutes the claims that educational institutions make toward objectivity, meritocracy, colorblindness, race neutrality and equal opportunity. CRT challenges notions of 'neutral' research or 'objective' researchers and exposes deficit-informed research that silences, ignores and distorts epistemologies of People of Color (Delgado Bernal, 1998; Ladson-Billings, 2000). CRT argues that these traditional claims 
act as a camouflage for the self-interest, power, and privilege of dominant groups in US society (Bell, 1987; Calmore, 1992; Solórzano, 1997).

3. The commitment to social justice. CRT is committed to social justice and offers a liberatory or transformative response to racial, gender and class oppression (Matsuda, 1991). Such a social justice research agenda exposes the 'interestconvergence' (Bell, 1987) of civil rights 'gains' in education and works toward the elimination of racism, sexism and poverty, as well as the empowerment of People of Color and other subordinated groups (Freire, 1970, 1973; Solórzano \& Delgado Bernal, 2001).

4. The centrality of experiential knowledge. CRT recognizes that the experiential knowledge of People of Color is legitimate, appropriate, and critical to understanding, analyzing and teaching about racial subordination (Delgado Bernal, 2002). CRT draws explicitly on the lived experiences of People of Color by including such methods as storytelling, family histories, biographies, scenarios, parables, cuentos, testimonios, chronicles and narratives (Bell, 1987, 1992, 1996; Delgado, 1989, 1993, 1995a, b, 1996; Espinoza, 1990; Olivas, 1990; Montoya, 1994; Carrasco, 1996; Solórzano \& Yosso, 2000, 2001, 2002a; Solórzano \& Delgado Bernal, 2001; Delgado Bernal \& Villalpando, 2002; Villalpando, 2003).

5. The transdisciplinary perspective. CRT goes beyond disciplinary boundaries to analyze race and racism within both historical and contemporary contexts, drawing on scholarship from ethnic studies, women's studies, sociology, history, law, psychology, film, theatre and other fields (Delgado, 1984, 1992; Olivas, 1990; Gotanda, 1991; Harris, 1994; Garcia, 1995; Gutiérrez-Jones, 2001).

These five themes are not new in and of themselves, but collectively they represent a challenge to the existing modes of scholarship. Informed by scholars who continue to expand the literature and scope of discussions of race and racism, I define CRT in education as a theoretical and analytical framework that challenges the ways race and racism impact educational structures, practices, and discourses. CRT is conceived as a social justice project that works toward the liberatory potential of schooling (hooks, 1994; Freire, 1970, 1973). This acknowledges the contradictory nature of education, wherein schools most often oppress and marginalize while they maintain the potential to emancipate and empower. Indeed, CRT in education refutes dominant ideology and White privilege while validating and centering the experiences of People of Color. CRT utilizes transdisciplinary approaches to link theory with practice, scholarship with teaching, and the academy with the community (see LatCrit Primer, 1999; Solórzano \& Yosso, 2001).

Many in the academy and in community organizing, activism, and service who look to challenge social inequality will most likely recognize the tenets of CRT as part of what, why and how they do the work they do. CRT addresses the social construct of race by examining the ideology of racism. CRT finds that racism is often well disguised in the rhetoric of shared 'normative' values and 'neutral' social scientific principles and practices (Matsuda et al., 1993). However, when the ideology of racism is examined and racist injuries are named, victims of racism can often find 
their voice. Those injured by racism and other forms of oppression discover that they are not alone and moreover are part of a legacy of resistance to racism and the layers of racialized oppression. They become empowered participants, hearing their own stories and the stories of others, listening to how the arguments against them are framed and learning to make the arguments to defend themselves.

\section{Challenging racism, revealing cultural wealth}

CRT's five tenets provide a helpful guiding lens that can inform research in Communities of Color. Looking through a CRT lens means critiquing deficit theorizing and data that may be limited by its omission of the voices of People of Color. Such deficitinformed research often 'sees' deprivation in Communities of Color. Indeed, one of the most prevalent forms of contemporary racism in US schools is deficit thinking. Deficit thinking takes the position that minority students and families are at fault for poor academic performance because: (a) students enter school without the normative cultural knowledge and skills; and (b) parents neither value nor support their child's education. These racialized assumptions about Communities of Color most often leads schools to default to the banking method of education critiqued by Paulo Freire (1973). As a result, schooling efforts usually aim to fill up supposedly passive students with forms of cultural knowledge deemed valuable by dominant society. Scholars Shernaz García and Patricia Guerra (2004) find that such deficit approaches to schooling begin with overgeneralizations about family background and are exacerbated by a limited framework to interpret how individual views about educational success are shaped by personal 'sociocultural and linguistic experiences and assumptions about appropriate cultural outcomes' (p. 163). Educators most often assume that schools work and that students, parents and community need to change to conform to this already effective and equitable system.

Indeed, García and Guerra's (2004) research acknowledges that deficit thinking permeates US society, and both schools and those who work in schools mirror these beliefs. They argue that this reality necessitates a challenge of personal and individual race, gender and class prejudices expressed by educators, as well as a 'critical examination of systemic factors that perpetuate deficit thinking and reproduce educational inequities for students from nondominant sociocultural and linguistic backgrounds' (p. 155). I believe CRT can offer such an approach by identifying, analyzing and challenging distorted notions of People of Color.

As part of the challenge to deficit thinking in education, it should be noted that race is often coded as 'cultural difference' in schools. Indeed, culture influences how society is organized, how school curriculum is developed and how pedagogy and policy are implemented. In social science, the concept of culture for Students of Color has taken on many divergent meanings. Some research has equated culture with race and ethnicity, while other work clearly has viewed culture through a much broader lens of characteristics and forms of social histories and identities. For my purposes here, culture refers to behaviors and values that are learned, shared, and exhibited by a group of people. Culture is also evidenced in material and nonmaterial productions of a people. 
Culture as a set of characteristics is neither fixed nor static (Gómez-Quiñones, 1977). For example, with Students of Color, culture is frequently represented symbolically through language and can encompass identities around immigration status, gender, phenotype, sexuality and region, as well as race and ethnicity.

Looking through a CRT lens, the cultures of Students of Color can nurture and empower them (Delgado-Gaitan, 2001; Delgado Bernal, 2002). Focusing on research with Latina/o families, Luis C Moll, Cathy Amanti, Deborah Neff and Norma Gonzalez (1992), Carlos Vélez-Ibáñez and James Greenberg (1992) and Irma Olmedo (1997) assert that culture can form and draw from communal funds of knowledge (Gonzalez et al., 1995; Gonzalez \& Moll, 2002). Likewise, Douglas Foley (1997) notes research revealing the 'virtues and solidarity in African American community and family traditions' as well as the 'deeply spiritual values passed from generation to generation in most African American communities' (p. 123).

Taken together, the CRT challenge to deficit thinking and understanding of the empowering potential of the cultures of Communities of Color, leads me to the following description of cultural wealth. I begin with a critique of the ways Bourdieu's (Bourdieu \& Passeron, 1977) work has been used to discuss social and racial inequity. In education, Bourdieu's work has often been called upon to explain why Students of Color do not succeed at the same rate as Whites. According to Bourdieu, cultural capital refers to an accumulation of cultural knowledge, skills and abilities possessed and inherited by privileged groups in society. Bourdieu asserts that cultural capital (i.e., education, language), social capital (i.e., social networks, connections) and economic capital (i.e., money and other material possessions) can be acquired two ways, from one's family and/or through formal schooling. The dominant groups within society are able to maintain power because access is limited to acquiring and learning strategies to use these forms of capital for social mobility.

Therefore, while Bourdieu's work sought to provide a structural critique of social and cultural reproduction, his theory of cultural capital has been used to assert that some communities are culturally wealthy while others are culturally poor. This interpretation of Bourdieu exposes White, middle class culture as the standard, and therefore all other forms and expressions of 'culture' are judged in comparison to this 'norm'. In other words, cultural capital is not just inherited or possessed by the middle class, but rather it refers to an accumulation of specific forms of knowledge, skills and abilities that are valued by privileged groups in society. For example, middle or upper class students may have access to a computer at home and therefore can learn numerous computer-related vocabulary and technological skills before arriving at school. These students have acquired cultural capital because computer-related vocabulary and technological skills are valued in the school setting. On the other hand, a working class Chicana/o student whose mother works in the garment industry may bring a different vocabulary, perhaps in two languages (English and Spanish) to school, along with techniques of conducting errands on the city bus and translating mail, phone calls and coupons for her/his mother (see Faulstich Orellana, 2003). This cultural knowledge is very valuable to the student and her/his family, but is not necessarily considered to carry any capital in the school context. So, are there forms of 
cultural capital that marginalized groups bring to the table that traditional cultural capital theory does not recognize or value? CRT answers, yes.

CRT shifts the center of focus from notions of White, middle class culture to the cultures of Communities of Color. In doing so, I also draw on the work of sociologists Melvin Oliver and Thomas Shapiro (1995) to better understand how cultural capital is actually only one form of many different aspects that might be considered valuable. Oliver and Shapiro (1995) propose a model to explain how the narrowing of the income or earnings gap between Blacks and Whites is a misleading way to examine inequality. They argue that one's income over a typical fiscal year focuses on a single form of capital and that the income gap between Blacks and Whites is narrowing over time. On the other hand, they examine separately the concept of wealth and define it as the total extent of an individual's accumulated assets and resources (i.e., ownership of stocks, money in bank, real estate, business ownership, etc). They then argue that while the income of Blacks may indeed be climbing and the Black/White income gap narrowing, their overall wealth, compared to Whites, is declining and the gap is diverging (see also Shapiro, 2004).

Traditional Bourdieuean cultural capital theory has parallel comparisons to Oliver and Shapiro's (1995) description of income. Both place value on a very narrow range of assets and characteristics. A traditional view of cultural capital is narrowly defined by White, middle class values, and is more limited than wealth-one's accumulated assets and resources. CRT expands this view. Centering the research lens on the experiences of People of Color in critical historical context reveals accumulated assets and resources in the histories and lives of Communities of Color.

Figure 2 demonstrates that community cultural wealth is an array of knowledge, skills, abilities and contacts possessed and utilized by Communities of Color to survive and resist macro and micro-forms of oppression. ${ }^{3}$

Indeed, a CRT lens can 'see' that Communities of Color nurture cultural wealth through at least 6 forms of capital such as aspirational, navigational, social, linguistic, familial, and resistant capital (see Delgado Bernal, 1997, 2001; Auerbach, 2001; Stanton-Salazar, 2001; Solórzano \& Delgado Bernal, 2001; Faulstich Orellana, 2003).These various forms of capital are not mutually exclusive or static, but rather are dynamic processes that build on one another as part of community cultural wealth. For example, as noted above, aspirational capital is the ability to hold onto hope in the face of structured inequality and often without the means to make such dreams a reality. Yet, aspirations are developed within social and familial contexts, often through linguistic storytelling and advice (consejos) that offer specific navigational goals to challenge (resist) oppressive conditions. Therefore, aspirational capital overlaps with each of the other forms of capital, social, familial, navigational, linguistic and resistant. As Anzaldúa asserts, 'In our mestizaje theories we create new categories for those of us left out of or pushed out of existing ones' (Anzaldúa, 1990, p. xxvi, emphasis in original).

1. Aspirational capital refers to the ability to maintain hopes and dreams for the future, even in the face of real and perceived barriers. This resiliency is evidenced 

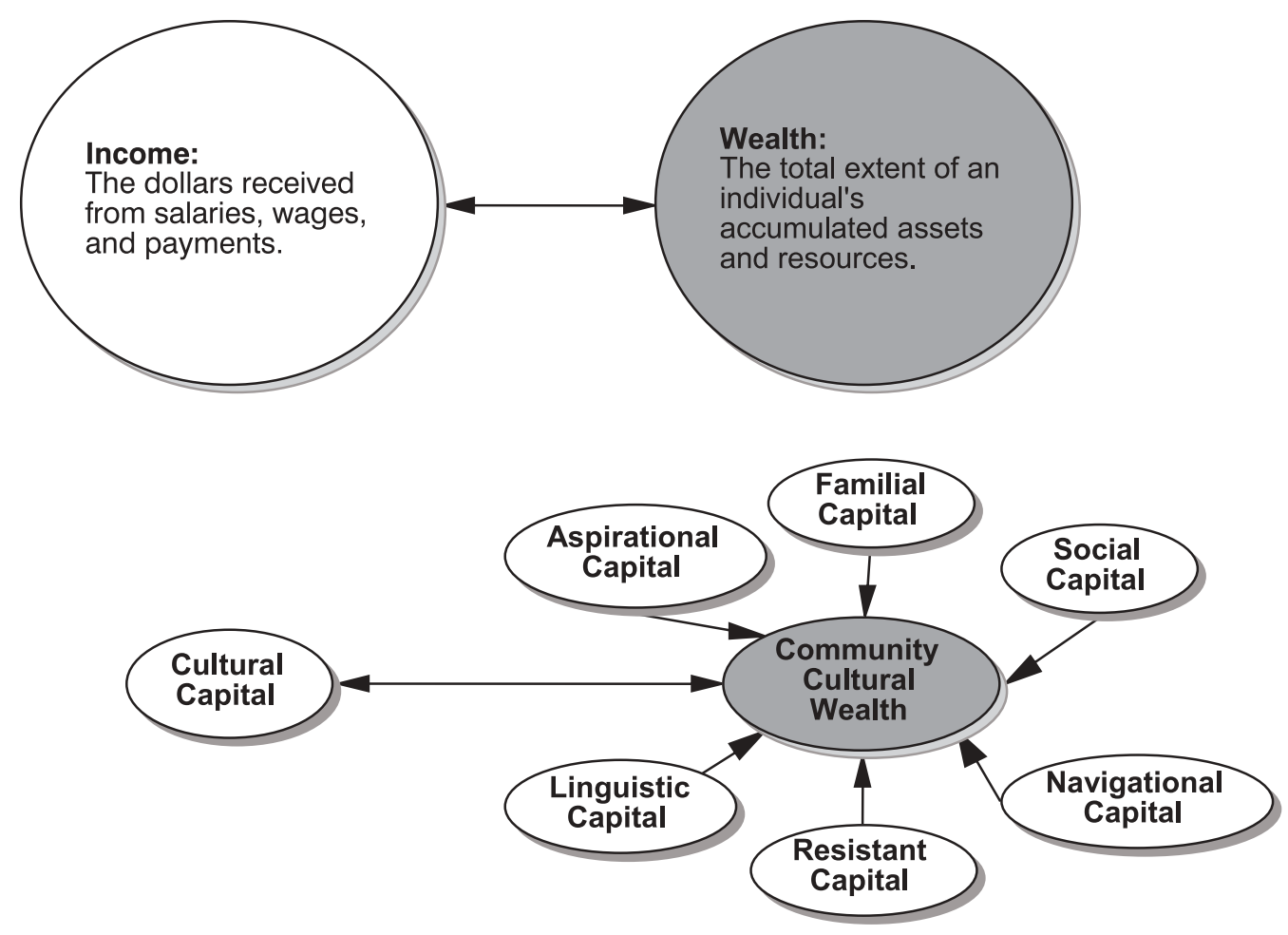

Figure 2. A model of community cultural wealth. Adapted from: Oliver \& Shapiro, 1995

in those who allow themselves and their children to dream of possibilities beyond their present circumstances, often without the objective means to attain those goals. This form of cultural wealth draws on the work of Patricia Gándara (1982, 1995) and others who have shown that Chicanas/os experience the lowest educational outcomes compared to every other group in the US, but maintain consistently high aspirations for their children's future (Delgado-Gaitan, 1992, 1994; Solórzano, 1992; Auerbach, 2001). These stories nurture a culture of possibility as they represent 'the creation of a history that would break the links between parents' current occupational status and their children's future academic attainment' (Gándara, 1995, p. 55).

2. Linguistic capital includes the intellectual and social skills attained through communication experiences in more than one language and/or style (see Faulstich Orellana, 2003). ${ }^{4}$ This aspect of cultural wealth learns from over 35 years of research about the value of bilingual education and emphasizes the connections between racialized cultural history and language (Cummins, 1986; Anzaldúa, 1987; Darder, 1991; García \& Baker, 1995; Gutierrez et al., 1995; Macedo \& Bartolomé, 1999; Gutierrez, 2002). Linguistic capital reflects the idea that Students of Color arrive at school with multiple language and communication skills. In addition, these children most often have been engaged participants in a storytelling tradition, that may include listening to and recounting oral histories, 
parables, stories (cuentos) and proverbs (dichos). This repertoire of storytelling skills may include memorization, attention to detail, dramatic pauses, comedic timing, facial affect, vocal tone, volume, rhythm and rhyme. Linguistic capital also refers to the ability to communicate via visual art, music or poetry. ${ }^{5}$ Just as students may utilize different vocal registers to whisper, whistle or sing, they must often develop and draw on various language registers, or styles, to communicate with different audiences. For example, Marjorie Faulstich Orellana (2003) examines bilingual children who are often called upon to translate for their parents or other adults and finds that these youth gain multiple social tools of 'vocabulary, audience awareness, cross-cultural awareness, "real-world" literacy skills, math skills, metalinguistic awareness, teaching and tutoring skills, civic and familial responsibility, [and] social maturity' (p. 6).

3. Familial capital refers to those cultural knowledges nurtured among familia (kin) that carry a sense of community history, memory and cultural intuition (see Delgado Bernal, 1998, 2002). This form of cultural wealth engages a commitment to community well being and expands the concept of family to include a more broad understanding of kinship. Acknowledging the racialized, classed and heterosexualized inferences that comprise traditional understandings of 'family', familial capital is nurtured by our 'extended family', which may include immediate family (living or long passed on) as well as aunts, uncles, grandparents and friends who we might consider part of our familia. From these kinship ties, we learn the importance of maintaining a healthy connection to our community and its resources. Our kin also model lessons of caring, coping and providing (educación), ${ }^{6}$ which inform our emotional, moral, educational and occupational consciousness (Reese, 1992; Auerbach, 2001, 2004; Elenes et al., 2001; Lopez, 2003). This consciousness can be fostered within and between families, as well as through sports, school, religious gatherings and other social community settings. Isolation is minimized as families 'become connected with others around common issues' and realize they are 'not alone in dealing with their problems' (Delgado-Gaitan, 2001, p. 54). Familial capital is informed by the work of scholars who have addressed the communal bonds within African American communities (Foley, 1997; Morris, 1999), the funds of knowledge within Mexican American communities (Moll et al., 1992; Vélez-Ibáñez \& Greenberg, 1992; Gonzalez et al., 1995; Olmedo, 1997; Rueda et al., 2004) and pedagogies of the home that Students of Color bring with them to the classroom setting (Delgado Bernal, 2002).

4. Social capital can be understood as networks of people and community resources. These peer and other social contacts can provide both instrumental and emotional support to navigate through society's institutions (see Gilbert, 1982; Stanton-Salazar, 2001). For example, drawing on social contacts and community resources may help a student identify and attain a college scholarship. These networks may help a student in preparing the scholarship application itself, while also reassuring the student emotionally that she/he is not alone in the process of pursuing higher education. Scholars note that historically, People of Color have 
utilized their social capital to attain education, legal justice, employment and health care. In turn, these Communities of Color gave the information and resources they gained through these institutions back to their social networks. Mutualistas or mutual aid societies are an example of how historically, immigrants to the US and indeed, African Americans even while enslaved, created and maintained social networks (Gómez-Quiñones, 1973, 1994; Gutman, 1976; Sanchez, 1993; Stevenson, 1996). This tradition of 'lifting as we climb' has remained the motto of the National Association of Colored Women's Clubs since their organization in 1896 (see Gurnier, Fine \& Balin, 1997, p. 167). Concha DelgadoGaitan's (2001) ethnographic research with the Mexican immigrant community of Carpinteria, California further confirms that 'Families transcend the adversity in their daily lives by uniting with supportive social networks' (p. 105).

5. Navigational capital refers to skills of maneuvering through social institutions. Historically, this infers the ability to maneuver through institutions not created with Communities of Color in mind. For example, strategies to navigate through racially-hostile university campuses draw on the concept of academic invulnerability, or students' ability to 'sustain high levels of achievement, despite the presence of stressful events and conditions that place them at risk of doing poorly at school and, ultimately, dropping out of school' (Alva, 1991, p. 19; see also Allen \& Solórzano, 2000; Solórzano et al., 2000; Auerbach, 2001). Scholars have examined individual, family and community factors that support Mexican American students' academic invulnerability-their successful navigation through the educational system (Arrellano \& Padilla, 1996). In addition, resilience has been recognized as 'a set of inner resources, social competencies and cultural strategies that permit individuals to not only survive, recover, or even thrive after stressful events, but also to draw from the experience to enhance subsequent functioning' (Stanton-Salazar \& Spina, 2000, p. 229). Indeed, People of Color draw on various social and psychological 'critical navigational skills' (Solórzano \& Villalpando, 1998) to maneuver through structures of inequality permeated by racism (see Pierce, 1974, 1989, 1995). Navigational capital thus acknowledges individual agency within institutional constraints, but it also connects to social networks that facilitate community navigation through places and spaces including schools, the job market and the health care and judicial systems (Williams, 1997).

6. Resistant capital refers those knowledges and skills fostered through oppositional behavior that challenges inequality (Freire, 1970, 1973; Giroux, 1983; McLaren, 1994; Delgado Bernal, 1997; Solórzano \& Delgado Bernal, 2001). This form of cultural wealth is grounded in the legacy of resistance to subordination exhibited by Communities of Color (Deloria, 1969). Furthermore, maintaining and passing on the multiple dimensions of community cultural wealth is also part of the knowledge base of resistant capital. For example, even from within internment camps, Japanese communities resisted racism by maintaining and nurturing various forms of cultural wealth (Wakatsuki Houston \& Houston, 1973). ${ }^{7}$ Extending on this history, Tracy Robinson and Janie Ward's 
(1991) research shows a group of African American mothers who consciously raise their daughters as 'resistors'. Through verbal and nonverbal lessons, these Black mothers teach their daughters to assert themselves as intelligent, beautiful, strong and worthy of respect to resist the barrage of societal messages devaluing Blackness and belittling Black women (Ward, 1996). Similarly, Sofia Villenas and Melissa Moreno (2001) discuss the contradictions Latina mothers face as they try to teach their daughters to valerse por si misma (value themselves and be self-reliant) within structures of inequality such as racism, capitalism and patriarchy. In each of these research studies, Parents of Color are consciously instructing their children to engage in behaviours and maintain attitudes that challenge the status quo. These young women are learning to be oppositional with their bodies, minds and spirits in the face of race, gender and class inequality. In analyzing students' historical and contemporary efforts to transform unequal conditions in urban high schools, Daniel Solórzano and Dolores Delgado Bernal (2001) reveal that resistance may include different forms of oppositional behavior, such as self-defeating or conformist strategies that feed back into the system of subordination. However, when informed by a Freirean critical consciousness (1970), or recognition of the structural nature of oppression and the motivation to work toward social and racial justice, resistance takes on a transformative form (see Solórzano \& Yosso, 2002b). Therefore, transformative resistant capital includes cultural knowledge of the structures of racism and motivation to transform such oppressive structures (Pizarro, 1998; Villenas \& Deyhle, 1999).

\section{Discussion}

Recently, The Fournal of African American History dedicated an entire issue to 'Cultural capital and African American education' (see Franklin, 2002). In this issue, Franklin (2002) defines cultural capital as 'the sense of group consciousness and collective identity' that serves as a resource 'aimed at the advancement of an entire group' (p. 177). Franklin (2002) goes on to explain that various forms of cultural capital 'became a major resource historically for the funding of African American schools and other educational institutions and programs' (pp. 177-178). This research indicates that 'African Americans were willing to contribute their time, energies, and financial and material resources to support these educational institutions because they knew they were important to the advancement of African Americans as a group (Franklin, 2002, pp. 177-178).

Furthermore, in discussing implications of his ethnographic work with two African American school communities in the US urban south and midwest, Jerome Morris (2004) explains, 'Black people shared their cultural capital with one another and developed their social capital (Black social capital) for survival and success in a segregated world bounded by the omnipresent forces of racism and discrimination' (p. 102). This scholarship documenting community mobilization efforts to create access and equity for African Americans in education, bolsters the examples of 
cultural wealth offered above. Such work also demonstrates that the forms of capital comprising community cultural wealth are engendered from within the context of a legacy of racism and are thus tied to a larger social and racial justice project (Perea et al., 2000). Morris (2004) asserts, 'it is important that social capital theory also consider the agency and sustenance that are characteristic of African American people, culture and institutions - apart from and in response to oppressive forces' (p. 102). Indeed, the main goals of identifying and documenting cultural wealth are to transform education and empower People of Color to utilize assets already abundant in their communities.

As demonstrated through the concept of cultural wealth, CRT research begins with the perspective that Communities of Color are places with multiple strengths. In contrast, deficit scholars bemoan a lack of cultural capital or what Hirsch (1988, 1996) terms 'cultural literacy' in low income Communities of Color. Such research utilizes a deficit analytical lens and places value judgments on communities that often do not have access to White, middle or upper class resources. In contrast, CRT shifts the research lens away from a deficit view of Communities of Color as places full of cultural poverty or disadvantages, and instead focuses on and learns from these communities' cultural assets and wealth (Solórzano \& Solórzano, 1995; Valencia \& Solórzano, 1997; Villalpando \& Solórzano, 2005).

CRT centers the research, pedagogy, and policy lens on Communities of Color and calls into question White middle class communities as the standard by which all others are judged. This shifting of the research lens allows critical race scholars to 'see' multiple forms of cultural wealth within Communities of Color. CRT identifies various indicators of capital that have rarely been acknowledged as cultural and social assets in Communities of Color (i.e., aspirational, social, navigational, linguistic, resistant and familial capital). These forms of capital draw on the knowledges Students of Color bring with them from their homes and communities into the classroom. They are not conceptualized for the purpose of finding new ways to co-opt or exploit the strengths of Communities of Color. ${ }^{8}$ Instead, community cultural wealth involves a commitment to conduct research, teach and develop schools that serve a larger purpose of struggling toward social and racial justice.

In the opening epigraph of this essay, Anzaldúa urges the generation of theories based on those whose knowledges are traditionally excluded from and silenced by academic research. She further asserts that beyond creating theories, 'we need to find practical application for those theories. We need to de-academize theory and to connect the community to the academy' (Anzaldúa, 1990, p. xxvi). Anzaldúa (2002) also notes that 'Change requires more than words on a page-it takes perseverance, creative ingenuity and acts of love' (p. 574). CRT offers a response to Anzaldúa's challenge in listening to the experiences of those 'faces at the bottom of society's well' (Bell, 1992, p. v). These experiences expose the racism underlying cultural deficit theorizing and reveal the need to restructure US social institutions around those knowledges, skills, abilities and networks - the community cultural wealthpossessed and utilized by People of Color. 


\section{Notes}

1. Although not exhaustive, the following resources are some examples of the different frameworks cited: ethnic studies (see Aztlan: A fournal of Chicano Studies); feminist studies (see Frontiers: A fournal of Women's Studies); cultural nationalist paradigms (see Asante, 1987); critical legal studies (see Kelman, 1989); Marxist and neo-Marxist frameworks (see Bowles \& Gintis, 1976; Barrera, 1979); internal colonial models (see Bonilla \& Girling, 1973); LatCrit (see Arriola, 1998; Valdes, 1997, 1998); WhiteCrit (see Delgado \& Sefancic, 1997); FemCrit (see Wing, 1997); AsianCrit (see Chang, 1993).

2. Solórzano and Yosso (2001) note that while each individual tenet of CRT is not 'new', synthesizing these tenets into a CRT framework in education is relatively recent. For instance, William Tate's 1994 autobiographical article in the journal Urban Education-titled 'From inner city to ivory tower: does my voice matter in the academy'-represents (to my knowledge) the first use of CRT principles in education. A year later, in 1995, Gloria Ladson-Billings and William Tate wrote a paper titled, 'Toward a critical race theory of education' in the Teachers College Record. Two years later, Daniel Solórzano's 1997 essay on 'Images and words that wound: critical race theory, racial stereotyping and teacher education' in Teacher Education Quarterly applied CRT to a specific subfield of teacher education. Also in 1997, William Tate's 'Critical race theory and education: history, theory and implications' in the Review of Research in Education furthered our understanding of the history of CRT in education. The field was expanded significantly with the 1998 'Special issue on critical race theory in education' in the International fournal of Qualitative Studies in Education. The 1999 edited book on Race is-race isn't: critical race theory and qualitative studies in education (Parker et al., 1999) was followed by individual scholars presenting on panels at professional conferences across the country and publishing their work in various journals. In 2002, the journals Qualitative Inquiry and Equity and Excellence in Education dedicated a special issue to CRT in education. In 2004, the American Education Research Association conference symposium 'And we are still not saved: critical race theory in education ten years later' acknowledged the ten year anniversary of Tate's 1994 article introducing CRT officially to education.

3. As is consistent with the concept of community cultural wealth, this working definition demonstrates an accumulation of collaborative work. Thank you to Daniel G Solórzano who originally conceptualized cultural wealth. He shared with me a model in progress and later a collaboratively written piece (with Octavio Villalpando), and asked me to 'run with it'. Since that time, cultural wealth has taken on multiple dimensions. I also acknowledge those personal and professional experiences, community histories and students' research projects that have informed this work. I look forward to the ways that cultural wealth will take on new dimensions as others also 'run with it'.

4. Thanks to Rebeca Burciaga, whose identification of linguistic and familial capital added important dimensions to cultural wealth.

5. Thanks to UCSB undergraduate students, Pablo Gallegos, Moises Garcia, Noel Gomez and Ray Hernandez, whose research conceptualizing graffiti and hip hop poetry as unacknowledged sources of community cultural wealth expanded my thinking about linguistic capital.

6. Chicana scholars note for example that in Spanish, educación holds dual meanings (DelgadoGaitan, 1992, 1994, 2001; Elenes et al., 2001). A person can be formally educated with multiple advanced degrees, but may still be rude, ignorant, disrespectful or unethical (immoral)—mal educada. On the other hand, a person with only a second grade formal education may be una persona bien educada or a well-mannered, kind, fair-minded, respectful (moral) individual.

7. The book Farewell to Manzanar (Wakatsuki Houston \& Houston, 1973) offers a first-hand account of some of the ways Japanese internees held onto hope, fostered caring, coping and responsibility, maintained skills of language, poetry, music, social networks and critical navigational skills, and challenged social and racial inequality. 
8. I recognize that the notion of capital may be associated with capitalism, which is a system that is exploitative and has historically been an oppressive force against Communities of Color. The concept of schooling itself can be contradictory, given that schools have historically oppressed Students of Color, while still having the potential to be transformative places of empowerment. Similarly, as viewed through mainstream media, hip-hop's contradictory nature offers an example of how historically some aspects of community cultural wealth are co-opted and utilized for exploitative purposes (see Spike Lee's film Baboozled, 2000). Still, hip-hop maintains amazing potential to be a revolutionary art form and transformative cultural expression that can inspire and inform social movement. I believe community cultural wealth and forms of capital nurtured in the histories of People of Color holds the same potential.

\section{Note on contributor}

Tara J. Yosso is an Assistant Professor in the Department of Chicana and Chicano Studies at the University of California, Santa Barbara. Her research and teaching focuses on educational equity utilizing the frameworks of critical race theory, LatCrit theory and critical media literacy.

\section{References}

Allen, W. (1993) A response to a 'white discourse on white racism', Educational Researcher, 22, 11-13.

Allen, W. \& Solórzano, D. (2001) Affirmative action, educational equity, and campus racial climate: A case study of the university of Michigan law school, Berkeley La Raza Law fournal, 12(2), 237-363.

Alva, S. (1991) Academic invulnerability among Mexican American students: the importance of protective resources and appraisals, Hispanic fournal of Behavioral Sciences, 13(1), 18-34.

Anzaldúa, G. (1987) Borderlands/La Frontera: the New Mestiza (San Francisco, CA, Aunt Lute Book Company).

Anzaldúa, G. (1990) Haciendo Caras/making face, making soul: creative and critical perspectives by women of color (San Francisco, CA, Aunt Lute Press).

Anzaldúa, G. (2002) Now let us shift ... the path of conocimiento ... inner work, public acts, in: G. Anzaldúa \& A. Keating (Eds) This bridge we call home: radical visions for transformation (New York, Routledge), 540-578.

Arrellano, A. R. \& Padilla, A. M. (1996) Academic invulnerability among a select group of Latino university students, Hispanic fournal of Behavioral Sciences, 18(4), 485-507.

Arriola, E. (1997) LatCrit theory, international human rights, popular culture and the faces of despair in ins raids, Inter-American Law Review, 28(2), 245-262.

Arriola, E. (1998) Difference, solidarity and law: building Latina/o communities through LatCrit theory, Chicano-Latino Law Review, 19, 1-612.

Asante, M. K. (1987) The Afrocentric idea (Philadelphia, PA, Temple University Press).

Auerbach, S. (2001) Under co-construction: parent roles in promoting college access for students of color, unpublished doctoral dissertation, University of California, Los Angeles.

Auerbach, S. (2004) From moral supporters to struggling advocates: reconceptualizing parent involvement through the experience of Latino families, paper presented at annual meeting of the American Educational Research Association. San Diego, CA.

Baca Zinn, M. (1989) Family, race and poverty in the eighties, Signs: Fournal of Woman in Culture and Society, 14, 856-874.

Barnes, R. (1990) Race consciousness: the thematic content of racial distinctiveness in critical race scholarship, Harvard Law Review, 103, 1864-1871. 
Barrera, M. (1979) Race and class in the southwest: a theory of inequality (London, University of Notre Dame Press).

Bell, D. (1986) Application of the 'tipping point' theory to law faculty hiring practices, Nova Law Fournal, 10, 319-327.

Bell, D. (1987) And we will not be saved: the elusive quest for racial justice (New York, Basic Books).

Bell, D. (1992) Faces at the bottom of the well: the permanence of racism (New York, Basic Books).

Bell, D. (1995) Who's afraid of critical race theory?, University of Illinois Law Review, 1995, 893-910.

Bell, D. (1996) Gospel choirs: psalms of survival for an alien land called home (New York, Basic Books).

Bell, D. (1998) Afrolantica legacies (Chicago, IL, Third World Press).

Blauner, B. (2001) Still the big news: racial oppression in America (Philadelphia, Temple University Press).

Bonilla, F. \& Girling, R. (Eds) (1973) Structures of dependency (Stanford, CA, Stanford Institute of Politics).

Bonilla-Silva, E. (2001) White supremacy and racism in the post civil rights era (Boulder, CO, Lynne Rienner Publishers).

Bourdieu, P. \& Passeron, J. (1977) Reproduction in education, society and culture (London, Sage).

Bowles, S. \& Gintis, H. (1976) Schooling in capitalistic America: educational reform and the contradictions of economic life (New York, Basic Books).

Brayboy, B. (2002) Tribal critical race theory in education, paper presentation at annual conference of the American Educational Research Association, New Orleans, LA, April.

Brayboy, B. (2001) Toward a tribal critical theory in higher education, paper presentation at Annual Conference of the Association for the Study of Higher Education, Richmond, VA.

Caldwell. P. (1995) A hairpiece: perspectives on the intersection of race and gender, in: R. Delgado (Ed.) Critical race theory: the cutting edge (Philadelphia, PA, Temple University Press), 267-277.

Calmore, J. (1992) Critical race theory, Archie Shepp and fire music: securing an authentic intellectual life in a multicultural world, Southern California Law Review, 65, 2129-2231.

Calmore, J. (1997) Exploring Michael Omi's 'messy' real world of race: an essay for 'naked people longing to swim free', Law and Inequality, 15, 25-82.

Carrasco, E. (1996) Collective recognition as a communitarian device: or, of course we want to be role models!, La Raza Law fournal, 9, 81-101.

Chang, R. (1993) Toward an Asian American legal scholarship: critical race theory, poststructuralism, and narrative space, California Law Review, 81, 1243.

Chang, R. (1998) Who's afraid of Tiger Woods?, Chicano-Latino Law Review, 19, 223.

Chon, M. (1995) On the need for Asian American narratives in law: ethnic specimens, native informants, storytelling and silences, UCLA Asian Pacific American Law fournal, 3(1), 4-32.

Crenshaw, K. (1989) Demarginalizing the intersection of race and sex: A Black feminist critique of antidiscrimination doctrine, feminist theory and antiracist politics, University of Chicago Legal Forum, 1989, 139-167.

Crenshaw, K. (1993) Mapping the margins: intersectionality, identity politics and the violence against Women of Color, Stanford Law Review, 43, 1241-1299.

Crenshaw, K., Gotanda, N., Peller, G. \& Thomas, K. (Eds) (1995) Critical race theory: the key writings that formed the movement (New York, The New Press).

Crenshaw, K. (2002) The first decade: critical reflections, or 'a foot in the closing door', in: F. Valdes, J. McCristal Culp \& A. Harris (Eds) Crossroads, directions and a new critical race theory (Philadelphia, PA, Temple University Press), 9-31.

Cummins, J. (1986) Bilingual education and anti-racist education, Interracial Books for Children Bulletin, 17(3\&4), 9-12.

Darder, A. (1991) Culture and power in the classroom: a critical foundation for bicultural education (New York, Bergin \& Garvey). 
Davis, P. (1989) Law as microaggression, The Yale Law fournal, 98, 1559-1577.

Delgado, R. (1984) The imperial scholar: reflections on a review of civil rights literature, University of Pennsylvania Law Review, 132, 561-578.

Delgado, R. (1988) Critical legal studies and the realities of race: does the fundamental contradiction have a corollary?, Harvard Civil Rights-Civil Liberties Law Review, 23, 407-413.

Delgado, R. (1989) Storytelling for oppositionists and others: a plea for narrative, Michigan Law Review, 87, 2411-2441.

Delgado, R. (1992) The imperial scholar revisited: how to marginalize outsider writing, ten years later, University of Pennsylvania Law Review, 140, 1349-1372.

Delgado, R. (1993) On telling stories in school: a reply to Farber and Sherry, Vanderbilt Law Review, 46, 665-676.

Delgado, R. (Ed.) (1995a) Critical race theory: the cutting edge (Philadelphia, PA, Temple University Press).

Delgado, R. (1995b) The Rodrigo chronicles: conversations about America and race (New York, New York University Press).

Delgado, R. (1996) The coming race war?: and other apocalyptic tales of American after affirmative action and welfare (New York, New York University Press).

Delgado, R. (1997) Rodrigo's fifteenth chronicle: racial mixture, Latino-critical scholarship, and the black-white binary, Texas Law Review, 75, 1181-1201.

Delgado, R. (1999) When equality ends: stories about race and resistance (Boulder, CO, Westview Press).

Delgado, R. (2003) Fustice at war: civil liberties and civil rights during times of crisis (New York, New York University Press).

Delgado, R. \& Stefancic, J. (1992) Images of the outsider in American law and culture: can free expression remedy systematic social ills?, Cornell Law Review, 77, 1258-1297.

Delgado, R. \& Stefancic, J. (1993) Critical race theory: an annotated bibliography, Virginia Law Review, 79, 461-516.

Delgado, R. \& Stefancic, J. (1994) Critical race theory: an annotated bibliography 1993, a year of transition, University of Colorado Law Review, 66, 159-193.

Delgado, R. \& Stefancic, J. (Eds) (1997) Critical white studies: looking behind the mirror (Philadelphia, Temple University Press).

Delgado, R. \& Stefancic, J. (2001) Critical race theory: an introduction (New York, New York University Press).

Delgado Bernal, D. (1997) Chicana school resistance and grassroots leadership: providing an alternative history of the 1968 East Los Angeles blowouts, unpublished doctoral dissertation, University of California, Los Angeles.

Delgado Bernal, D. (1998) Using a Chicana feminist epistemology in educational research, Harvard Educational Review, 68(4), 555-582.

Delgado Bernal, D. (2001) Living and learning pedagogies of the home: the mestiza consciousness of Chicana students, International fournal of Qualitative Studies in Education, 14(5), 623-639.

Delgado Bernal, D. (2002) Critical race theory, LatCrit theory and critical raced-gendered epistemologies: recognizing Students of Color as holders and creators of knowledge, Qualitative Inquiry, 8(1), 105-126.

Delgado Bernal, D. \& Villalpando, O. (2002) An apartheid of knowledge in academia: the struggle over the 'legitimate' knowledge of Faculty of Color, Equity and Excellence in Education, 35(2), 169-180.

Delgado-Gaitan, C. (1992) School matters in the Mexican American home: socializing children to education, American Educational Research fournal, 29(3), 495-513.

Delgado-Gaitan, C. (1994) Socializing young children in Mexican-American families: an intergenerational perspective, in: P. Greenfield \& R. Cocking (Eds) Cross-cultural roots of minority development (New Jersey, Lawrence Erlbaum Associates), 55-86.

Delgado-Gaitan, C. (2001) The power of community: mobilizing for family and schooling (Boulder, CO, Rowman and Littlefield Publishers). 
Deloria, V. (1969) Custer died for your sins: an Indian manifesto (New York, Avon).

DuBois, W. E. B. (1989) The soul of black folks (New York, Bantam). (Originally published in 1903.)

Elenes, C. A., Gonzalez, F., Delgado Bernal, D. \& Villenes, S. (2001) Introduction: Chicana/ Mexicana feminist pedagogies: Consejos respeto, y educación, International fournal of Qualitative Studies in Education, 14(5), 595-602.

Ellison, R. (1990) Invisible man (New York, Vintage Books).

Espinoza, L. G. (1990) Masks and other disguises: exposing legal academia, Harvard Law Review, $103,1878-1886$.

Espinoza, L. G. (1998) Latino/a identity and multi-identity: community and culture, in: R. Delgado \& J. Stefancic (Eds) The Latinola condition: a critical reader (New York, New York University Press), 17-23.

Espinoza, L. \& Harris, A. (1998) Embracing the tar-baby: LatCrit theory and the sticky mess of race, La Raza Law fournal, 10(1), 499-559.

Essed, P. (1991) Understanding everyday racism: an interdisciplinary theory (Newbury Park, Sage Publications).

Faulstich Orellana, M. (2003) In other words: en otras palabras: learning from bilingual kids' translating/interpreting experiences (Evanston, IL, School of Education and Social Policy, Northwestern University).

Fay, B. (1987) Critical social science: liberation and its limits (Ithaca, NY, Cornell University Press).

Foley, D. E. (1997) Deficit thinking models based on culture: the anthropological protest, in: R. Valencia (Ed.) The evolution of deficit thinking: educational thought and practice (London, The Falmer Press), 113-131.

Franklin, V. P. (2002) Introduction: cultural capital and African-American education, The fournal of African-American History, 87, 175-181.

Freire, P. (1970) Education for critical consciousness (New York, Continuum Publishing Company).

Freire, P. (1973) Pedagogy of the oppressed (New York, The Seabury Press).

Gándara, P. (1982) Passing through the eye of the needle: high-achieving Chicanas, Hispanic Fournal of Behavioral Sciences, 4, 167-179.

Gándara, P. (1995) Over the ivy walls: the educational mobility of low-income Chicanos (Albany, State University of New York Press).

Garcia, R. (1995) Critical race theory and proposition 187: the racial politics of immigration law, Chicano-Latino Law Review, 17, 118-148.

García, O. \& Baker, C. (1995) Policy and practice in bilingual education: a reader extending the foundations (Philadelphia, Multilingual Matters).

García, S. B. \& Guerra, P. L. (2004) Deconstructing deficit thinking: working with educators to create more equitable learning environments, Education and Urban Society, 36(2), 150-168.

Gilbert, M. J. (1982) Los parientes: social structural factors and kinship relations among second generation Mexican Americans in two southern California communities, unpublished doctoral dissertation, University of California, Santa Barbara.

Giroux, H. (1983) Theories of reproduction and resistance in the new sociology of education: a critical analysis, Harvard Educational Review, 55, 257-293.

Gómez-Quiñones, J. (1973) The first steps: Chicano labor conflict and organizing 1900-1920, Aztlan, 3(1), 13-49.

Gómez-Quiñones, J. (1977) On culture (New York, UCLA Chicano Studies Center Publications).

Gómez-Quiñones, J. (1994) Roots of Chicano politics, 1600-1940 (Albuquerque, NM, University of New Mexico Press).

Gonzalez, N. \& Moll, L. C. (2002) Cruzando el puente: building bridges to funds of knowledge, Educational Policy, 16(4), 623-641.

Gonzalez, N., Moll, L. C., Tenery, M. F., Rivera, A., Rendon, P. Gonzales, R. \& Amanti, C. (1995) Funds of knowledge for teaching in Latino households, Urban Education, 29(4), 443-470. 
Gotanda, N. (1991) A critique of 'our constitution is color-blind', Stanford Law Review, 44, 1-68.

Guinier, L., Fine, M. \& Balin, J. (1997) Becoming gentleman: women, law school, and institutional change (Boston, MA, Beacon Press).

Gutiérrez, K. (2002) Studying cultural practices in urban learning communities, Human Development, 45(4), 312-321.

Gutiérrez-Jones, C. (2001) Critical race narratives: a study of race, rhetoric and injury (New York, New York University Press).

Gutman, H. (1976) The Black family in slavery and freedom, 1750-1925 (New York, Pantheon Books).

Harris, A. (1994) Forward: the jurisprudence of reconstruction, California Law Review, 82, 741-785.

Hill Collins, P. (1986) Learning from the outsider within: the sociological significance of Black feminist thought, Social Problems, 33, S14-S32.

Hill Collins, P. (1998) Fighting words: Black women and the search for justice (Minneapolis, MN, University of Minnesota Press).

Hill Collins, P. (2000) Black feminist thought: knowledge, consciousness and the politics of empowerment (New York, Routledge).

Hirsch, E. D. Jr. (1988) Cultural literacy: what every American needs to know (New York, Vintage Books).

Hirsch, E. D. Jr. (1996) The schools we need and why we don't have them (New York, Doubleday).

hooks, b. (1990) Yearning: race, gender and cultural politics (Cambridge, MA, South End Press).

hooks, b. (1994) Teaching to transgress: education as the practice of freedom (New York, NY, Routledge).

Hurtado, A. (1996) The color of privilege: three blasphemes on race and feminism (Ann Arbor, University of Michigan Press).

Ikemoto, L. (1992) Furthering the inquiry: race, class and culture in the forced medical treatment of pregnant women, Tennessee Law Review, 59, 487.

Johnson, K. (1999) How did you get to be Mexican? A Whitelbrown man's search for identity (Philadelphia, PA, Temple University Press).

Ladson-Billings, G. (1998) Preparing teachers for diverse student populations: a critical race theory perspective, Review of Research in Education, 24, 211-247.

Ladson-Billings, G. (2000) Racialized discourses and ethnic epistemologies, in: N. Denzin \& Y. Lincoln (Eds) Handbook of qualitative research (Thousand Oaks, CA, Sage), 257-277.

Ladson-Billings, G. \& Tate, W. (1995) Toward a critical race theory of education, Teachers College Record, 97, 47-68.

LatCrit Primer (1999) Fact sheet: LatCrit, presented to the Fourth Annual LatCrit Conference, Stanford Sierra Conference Center, Lake Tahoe, Nevada, 29 April-5 May.

Lawrence, C. (1987) The id, the ego, and equal protection: reckoning with unconscious racism, Stanford Law Review, 39, 317-388.

Lawrence, C. (1992) The word and the river: pedagogy as scholarship as struggle, Southern California Law Review, 65, 2231-2298.

Lawrence, C. \& Matsuda, M. (1997) We won't go back: making the case for affirmative action (Boston, MA, Houghton Mifflin).

Lawson, R. (1995) Critical race theory as praxis: a view from outside to the outside, Howard Law fournal, 38, 353-370.

Lopez, G. (2003) Parental involvement as racialized performance, in: G. Lopez \& L. Parker (Eds) Interrogating racism in qualitative research methodology (New York, Peter Lang Publishing), 71-95.

Lopez, G. \& Parker, L. (Eds) (2003) Interrogating racism in qualitative research methodology (New York, Peter Lang Publishing).

Lynn, M. (1999) Toward a critical race pedagogy: a research note, Urban Education, 33, 606-626.

Lynn, M. \& Adams, M. (Eds) (2002) Special issue of critical race theory in education, Equity and Excellence in Education, 35(2), 87-199. 
Lynn, M., Yosso, T., Solórzano, D. \& Parker, L. (2002) Special issue: critical race and qualitative research, Qualitative Inquiry, 8(1), 3-126.

Macedo. D. \& Bartolomé, L. (1999) Dancing with bigotry: beyond the politics of tolerance (New York, Palgrave).

Marable, M. (1992) Black America (Westfield, NJ, Open Media).

Matsuda, M. (1991) Voices of America: accent, antidiscrimination law and a jurisprudence for the last reconstruction, Yale Law Fournal, 100, 1329-1407.

Matsuda, M., Lawrence, C., Delgado, R. \& Crenshaw, K. (1993) Words that wound: critical race theory, assaultive speech, and the first amendment (Boulder, CO, Westview Press).

McLaren, P. (1994) Life in schools: an introduction to critical pedagogy in the foundations of education (2nd edn) (New York, Longman).

Moll, L. C., Amanti, C., Neff, D. \& Gonzalez, N. (1992) Funds of knowledge for teaching: using a qualitative approach to connect homes and classrooms, Theory into Practice, 31(2), 132-141.

Montoya, M. (1994) Mascaras, trenzas, y grenas: un/masking the self while un/braiding Latina stories and legal discourse, Chicano-Latino Law Review, 15, 1-37.

Montoya, M. (2002) Celebrating racialized legal narratives, in: F. Valdes, J. McCristal Culp \& A. Harris (Eds) Crossroads, directions and a new critical race theory (Philadephia, PA, Temple University Press), 243-250.

Moraga, C. (1983) La güera, in: C. Moraga \& G. Anzaldúa (Eds) This bridge called my back: writings by radical women of color (2nd edn) (New York, Kitchen Table), 24-33.

Morris, J. (1999) A pillar of strength: an African-American school's communal bonds with families and community since Brown, Urban Education, 33(5), 584-605.

Morris, J. (2004) Can anything good come from Nazareth? Race, class and African-American schooling and community in the urban south and Midwest, American Educational Research Fournal, 41(1), 69-112.

Olivas, M. (1990) The chronicles, my grandfather's stories and immigration law: the slave traders chronicle as racial history, Saint Louis University Law fournal, 34, 425-441.

Oliver, M. \& Shapiro, T. (1995) Black wealth/White wealth: a new perspective on racial inequality (New York, Routledge).

Olmedo, I. M. (1997) Voices of our past: using oral history to explore funds of knowledge within a Puerto Rican family, Anthropology and Education Quarterly, 28(4), 550-573.

Parker, L. Deyhle, D., Villenas, S. \& Crossland, K. (1998) Special issue: critical race theory and education, International fournal of Qualitative Studies in Education, 11, 1-184.

Parker, L., Deyhle, D. \& Villenas, S. (Eds) (1999) Race is ... race isn't: critical race theory and qualitative studies in education (Boulder, CO, Westview Press).

Perea, J., Delgado, R., Harris, A. \& Wildman, S. (2000) Race and races: cases and resources for a multiracial America (St Paul, MN, West Group).

Pierce, C. (1974) Psychiatric problems of the Black minority, in: S. Arieti (Ed.) American handbook of psychiatry (New York, Basic Books), 512-523.

Pierce, C. (1989) Unity in diversity: thirty-three years of stress, in: G. Berry \& J. Asamen (Eds) Black students: psychological issues and academic achievement (Newbury Park, Sage), 296-312.

Pierce, C. (1995) Stress analogs of racism and sexism: terrorism, torture, and disaster, in: C. Willie, P. Rieker, B. Kramer \& B. Brown (Eds) Mental health, racism and sexism (Pittsburgh, PA, University of Pittsburgh Press), 277-293.

Pizarro, M. (1998) 'Chicano power!' Epistemology and methodology for social justice and empowerment in Chicana/o communities, International fournal of Qualitative Studies in Education, 11(1), 57-80.

Reese, L. J. (1992) Ecocultural factors influencing the academic success of young Latino students, unpublished doctoral dissertation, University of California, Los Angeles.

Robinson, T. \& Ward, J. (1991) 'A belief in self far greater than anyone's belief': cultivating resistance among African-American female adolescents, in: C. Gilligan, A. Rogers \& D. Tolman (Eds) Women, girls and psychotherapy: reframing resistance (New York, Haworth), 87-103. 
Rueda, R., Monzo, L. D. \& Higareda, I. (2004) Appropriating the sociocultural resources of Latino paraeducators for effective instruction with Latino students: promises and problems, Urban Education, 29(1), 52-90.

Russell, M. (1992) Entering great America: reflections on race and the convergence of progressive legal theory and practice, Hastings Law fournal, 43, 749-767.

Saldivar-Hill, S. (2000) Feminism on the border: Chicana gender politics and literature (Berkeley, CA, University of California Press).

Scheurich, J. \& Young, M. (1997) Coloring epistemologies: are our research epistemologies racially biased?, Educational Researcher, 26, 4-16.

Shapiro, T. (2004) The hidden cost of being African-American: how wealth perpetuates inequality (New York, Oxford University Press).

Solórzano, D. (1989) Teaching and social change: reflections on a Freirean approach in a college classroom, Teaching Sociology, 17, 218-225.

Solórzano, D. (1992) Chicano mobility aspirations: a theoretical and empirical note, Latino Studies Fournal, 3, 48-66.

Solórzano, D. (1997) Images and words that wound: critical race theory, racial stereotyping and teacher education, Teacher Education Quarterly, 24, 5-19.

Solórzano, D. (1998) Critical race theory, racial and gender microaggressions, and the experiences of Chicana and Chicano Scholars, International fournal of Qualitative Studies in Education, 11, 121-136.

Solórzano, D., Ceja, M. \& Yosso, T. (2000) Critical race theory, racial microaggressions and campus racial climate: the experiences of African-American college students, fournal of Negro Education, 69(1/2), 60-73.

Solórzano, D. \& Delgado Bernal, D. (2001) Critical race theory, transformational resistance and social justice: Chicana and Chicano students in an urban context, Urban Education, 36, 308-342.

Solórzano, D. \& Solórzano, R. (1995) The Chicano educational experience: a proposed framework for effective schools in Chicano communities, Educational Policy, 9, 293-314.

Solórzano, D. \& Villalpando, O. (1998) Critical race theory, marginality, and the experience of minority students in higher education, in: C. Torres \& T. Mitchell (Eds) Emerging issues in the sociology of education: comparative perspectives (New York, SUNY Press), 211-224.

Solórzano, D. \& Yosso, T. (2000) Toward a critical race theory of Chicana and Chicano education, in: C. Tejeda, C. Martinez, Z. Leonardo \& P. McLaren (Eds) Charting new terrains of Chicana (o)/Latina (o) education (Cresskill, NJ, Hampton Press), 35-65.

Solórzano, D. \& Yosso, T. (2001) Critical race and LatCrit theory and method: counterstorytelling Chicana and Chicano graduate school experiences, International Fournal of Qualitative Studies in Education, 14(4), 471-495.

Solórzano, D. \& Yosso, T. (2002a) A critical race counterstory of race, racism and affirmative action, Equity and Excellence in Eduction, 35(2), 155-168.

Solórzano, D. \& Yosso, T. (2002b) Maintaining social justice hopes within academic realities: a freirean approach to critical race/LatCrit pedagogy, Denver Law Review, 78(4), 595-621.

Stanton-Salazar, R. D. (2001) Manufacturing hope and despair: the school and kin support networks of US-Mexican youth (New York, Teachers College Press).

Stanton-Salazar, R. \& Spina, S. U. (2000) The network orientations of highly resilient urban minority youth: a network-analytic account of minority socialization and its educational implications, The Urban Review, 32(3), 227-261.

Stefancic, J. (1998) Latino and Latina critical theory: an annotated bibliography, La Raza Law Fournal, 10, 423-498.

Stevenson, B. (1996) Life in Black and White: family and community in the slave south (New York, Oxford University Press).

Tate, W. (1994) From inner city to ivory tower: does my voice matter in the academy?, Urban Education, 29(3), 245-269. 
Tate, W. (1997) Critical race theory and education: history, theory and implications, Review of Research in Education, 22, 191-243.

Tatum, B. D. (1997) Why are all the Black kids sitting together in the cafeteria? And other conversations about race (New York, Basic Books).

Tierney, W. (1993) Building Communities of difference: higher education in the twenty-first century (Westport, CT, Bergin \& Garvey).

US Bureau of the Census (2000) 2000 census of the population: general population characteristics, United States summary (Washington, DC, US Government Printing Office).

Valdes, F. (1997) LatCrit theory: naming and launching a new direction of critical legal scholarship, Harvard Latino Law Review, 2, 1-501.

Valdes, F. (1998) LatCrit: Latinas/os and the law, La Raza Law Fournal, 10, 1-600.

Valdes, F., McCristal Culp, J. \& Harris, A. (2002) Crossroads, directions and a new critical race theory (Philadelphia, PA, Temple University Press), 243-250.

Valencia, R. (1991) Chicano school failure and success: research and policy agenda for the 1990s (New York, Falmer Press).

Valencia, R. (2002) Chicano school failure and success: past, present and future (New York, Routledge/ Falmer).

Valencia, R. \& Solórzano, D. (1997) Contemporary deficit thinking, in: R. Valencia (Ed.) The evolution of deficit thinking in educational thought and practice (New York, Falmer Press), 160-210.

Valenzuela, A. (1999) Subtractive schooling: US-Mexican youth and the politics of caring (New York, SUNY Press).

Vélez-Ibáñez, C. \& Greenberg, J. (1992) Formation and transformation of funds of knowledge among U.S.-Mexican households, Anthropology and Education Quarterly, 23(4), 313-335.

Villalpando, O. (2003) Self-segregation or self-preservation? A critical race theory and Latina/o critical theory analysis of findings form a longitudinal study of Chicana/o college students, International fournal of Qualitative Studies in Education, 16(5), 619-646.

Villalpando, O. \& Solórzano, D. (2005) The role of culture in college preparation programs: a review of the literature, in: W. Tierney, Z. Corwin, \& J. Kolyar (Eds) Preparing for college: nine elements of effective outreach (Albany, NY, SUNY Press), 13-28.

Villenas, S. \& Deyhle, D. (1999) Critical race theory and ethnographies challenging the stereotypes: Latino families, schooling, resilience and resistance, Curriculum Inquiry, 29(4), 413-445.

Villenas, S. \& Moreno, M. (2001) To valerse por si misma between race, capitalism, and patriarchy: Latina mother-daughter pedagogies in north Carolina, International fournal of Qualitative Studies in Education, 14(5), 671-688.

Wakatsuki Houston, J. \& Houston, J. D. (1973) Farewell to Manzanar: a true story of fapanese American experience during and after the World War II internment (Boston, Houghton Mifflin).

Ward, J. (1996) Raising resisters: the role of truth telling in the psychological development of African-American girls, in: B. Leadbetter \& N. Way (Eds) Urban girls: resisting stereotypes, creating identities (New York, New York University Press), 85-99.

Williams, P. (1991) The alchemy of race and rights: diary of a law professor (Cambridge, MA, Harvard University Press).

Williams, P. (1997) Spirit-murdering the messenger: the discourse of fingerprinting as the law's response to racism, in: A. Wing (Ed.) Critical race feminism: a reader (New York, New York University Press), 229-236.

Williams, R. (1997) Vampires anonymous and critical race practice, Michigan Law Review, 95, 741-765.

Wing, A. (Ed.) (1997) Critical race feminism: a reader (New York, New York University Press).

Wing, A. (Ed.) (2000) Global critical race feminism: an international reader (New York, New York University Press).

Zavella, P. (1991) Reflections on diversity among Chicanas, Frontiers: A fournal of Women Studies, 2(2), 73-85. 